\title{
SISTEM INFORMASI HAFALAN TERBAIK DALAM MUNAQOSAH TAHFIZHUL QUR'AN MENGGUNAKAN METODE AHP
}

\author{
Dini Indriani ${ }^{1}$, Ai llah Warnilah ${ }^{2}$ \\ ${ }^{1}$ Sistem Informasi,Kampus Kota Tasikmalaya ,'Sistem Informasi, Kampus Kota Tasikmalaya \\ e-mail: *1diniindriani00@gmail.com, ${ }^{2}$ ai.aiw@bsi.ac.id
}

\begin{abstract}
History has noted that before Islam came and before the Quran was revealed, the world is currently in a state of jahiliyah/ignorance.then Islam came with the Quran which was brought by Rasulullah, the friends were very excited about studying the Quran and the salafus shaleh they began to study starting with learning and memorizing the Quran so that Islam has succeeded in printing many scholars who have multidisciplinary knowledge, for the sake of printing a hight quality quran generation students who have strong memorization skills are needed (mutqin). Rumah Tahfizh Madena needs a method to simplify and speed up the decision making process by solving the problem into its parts. For this reason the author tries to make the final task regarding the design of information systems choosing the best rote students in munaqosah tahfizhul quran using the AHP method. Rumah Tahfizh Madena is a foundation of tahfizh institution under the auspices of FHQ (Forum Huffazhil Quran) which focuses on teaching memorization of the Quran. The system in Rumah Tahfizh Madena is still done manually, starting from data collection of santri munaqosah, data storage data from the assessment of munaqosah, determination of the best rote student to make report, so that it is possible during the process to occur errors in the recording process, less accurate and late reports made and delays in the search for data needed,information system design using the AHP method is the best solution to solve the problems that exist in Rumah Tahfizh Madena. With a decision support system the selection of the best computer based rote students can help decision makers in an institution house tahfizh in deciding the best alternatives.
\end{abstract}

Keywords_Information system design, selection of the best rote students, Munaqosah Tahfizhul Quran, AHP Method

Abstrak- Sejarah telah mencatat bahwa sebelum Islam datang dan sebelum Al-Qur'an diturunkan, dunia saat itu sedang dalam keadaan jahiliyah/kebodohan, kemudian Islam datang dengan Al-Qur'an yang dibawa oleh Rasulullah yang mulia, para sahabat sangat bersemangat sekali dalam mempelajari Al-Qur'an dan para salafus shaleh pun mereka mengawali menuntut ilmu mulai dengan belajar dan menghafal Al-Qur'an sehingga Islam telah berhasil mencetak banyak ulama yang mempunyai multidisiplin ilmu. Demi mencetak generasi qur'ani yang berkualitas tinggi, dibutuhkan santri yang memiliki kemampuan hafalan yang mutqin (kuat). Rumah Tahfizh Madena membutuhkan metode dalam menyederhanakan dan mempercepat proses pengambilan keputusan dengan memecahkan persoalan tersebut kedalam bagian-bagiannya. Untuk itulah penulis mencoba membuat Tugas Akhir mengenai perancangan sistem informasi pemilihan santri hafalan terbaik dalam munaqosah tahfizhul quran menggunakan metode AHP. Rumah Tahfizh Madena adalah Sebuah Yayasan Lembaga Tahfizh dibawah naungan FHQ (Forum Huffazhil Qur'an) yang fokus pada pengajaran menghafal Alqur'an. Sistem yang ada pada Rumah Tahfizh Madena masih dilakukan secara manual, mulai dari pendataan santri munaqosah, penyimpanan data-data hasil penilaian munaqosah, penentuan santri hafalan terbaik sampai pembuatan laporan, sehingga memungkinkan pada saat proses berlangsung terjadi kesalahan dalam proses pencatatan, kurang akurat dan terlambatnya laporan yang dibuat serta keterlambatan dalam pencarian data-data yang diperlukan. Perancangan sistem informasi menggunakan metode AHP ini merupakan solusi yang terbaik untuk memecahkan permasalahanpermasalahan yang ada pada Rumah Tahfizh Madena. Dengan sistem pendukung keputusan pemilihan santri hafalan terbaik yang berbasis komputer dapat membantu para pembuat keputusan di suatu lembaga rumah tahfizh dalam memutuskan alternatif-alternatif terbaik.

Kata kunci-PerancanganSistemlnformasi, Pemilihan Santri Hafalan Terbaik, Munaqosah Tahfizhul Quran, Metode AHP 


\section{A. PENDAHULUAN}

Sejarah telah mencatat bahwa sebelum Islam datang dan sebelum Al-Qur'an diturunkan, dunia saat itu sedang dalam keadaan jahiliyah/kebodohan. Keadaan bangsa Arab pada saat itu memiliki beberapa tradisi dan prosesi-prosesi didalam penyembahan berhala, mereka mempersembahkan korban untuk berhalaberhala itu.

Kemudian Islam datang dengan Al-Qur'an yang dibawa oleh Rasulullah yang mulia, kemudian para sahabat sangat bersemangat sekali dalam mempelajari Al-Qur'an, dan para salafus shaleh pun mereka mengawali menuntut ilmu mulai dengan belajar dan menghafal Al-Qur'an, sehingga Islam telah berhasil mencetak banyak ulama yang mempunyai multidisiplin ilmu, bisa membangun dan memimpin dunia sehingga sampai dua belas abad lebih.

Salah satu Lembaga Pendidikan Non Formal di wilayah Tasikmalaya yang menyelenggarakan program tahfizh (menghafal) Al-Qur'an yaitu Yayasan Rumah Tahfizh Madena. Sebuah YayasanLembaga Tahfizh dibawah naungan FHQ (Forum Huffazhil Qur'an) yang fokus pada pengajaran menghafal Al-qur'an, demi mencetak generasi qur'ani yang berkualitas tinggi, dibutuhkan santri yang memiliki kemampuan hafalan yang mutqin (kuat), Maka dari itu setiap 6 bulan atau 1 semester sekali Madena Tahfizh Qur'an melaksanakan Munaqosah (ujian) Tahfizhul Qur'an untuk bisa mengikuti wisuda.

Dalam pelaksanaannya pemilihan santrihafalan terbaik dalam MunaqosahTahfizhul Qur'an inimenggunakan beberapa komponen atau kriteria (multikriteria) yang nantinya akan dinilai.

Proses pemilihan santri hafalan terbaik dalam MunaqosahTahfizhul Qur'an merupakan permasalahan yang melibatkan banyak komponen atau kriteria yang dinilai (multikriteria), sehingga dalam penyelesaiannya diperlukan sebuah sistem pendukung keputusan dengan multikriteria.

Salah satu metode sistem pendukung keputusan yang multikriteria adalah Analytical Hierarchy Process (AHP). AHP ini cukup efektif dalam menyederhanakan dan mempercepat proses pengambilan keputusan dengan memecahkan persoalan tersebut kedalam bagian-bagiannya.

Berdasarkan masalah diatas penulis membuat sebuah sistem pendukung keputusan pemilihan santri hafalan terbaik dalam Munaqosah Tahfizhul Qur'an yang berbasis komputer dan diharapkan nantinya dapat membantu para pembuat keputusan di suatu lembaga rumah tahfizh dalam memutuskan alternatif-alternatif terbaik dalam pemilihan santri hafalan terbaik dalam Munaqosah Tahfizhul Qur'an

\section{B. TINJAUAN PUSTAKA \\ Sistem Pendukung Keputusan}

Menurut(Darmanto et al. 2014:76):

Sistem Penunjang Keputusan adalah sistem yang membantu pengambil keputusan dengan melengkapi mereka dengan informasi dari data yang telah diolah dengan relevan dan diperlukan untuk membuat keputusan tentang suatu masalah dengan lebih cepat dan akurat. Sehingga sistem ini tidak dimaksudkan untuk menggantikan pengambilan keputusan dalam proses pembuatan keputusan.

Menurut(Darmanto et al., 2014:76)komponen sistem penunjang keputusan terdiri dari:

1. Data Management (Manajemen Data)

Merupakan komponen SPK sebagai penyedia data bagi sistem, yang mana data disimpan dalam Database Management System(DBMS), sehingga dapat diambil dan diekstraksi dengan cepat.

2. Model Management (Manajemen Model) Melibatkan model finansial, statistikal, manajemen science, atau berbagai model kuantitatif lainnya, sehingga dapat memberikan ke sistem suatu kemampuan analistis, dan manajemen software yang diperlukan.

3. Communication (Dialog Subsistem) User dapat berkomunikasi dan memberikan perintah pada SPK melalui subsistem ini. Ini berarti menyediakan antarmuka.

4. Knowledge (Manajemen Pengetahuan)

Subsistem optional ini dapat mendukung subsistem lain atau bertindak sebagai komponen yang berdiri sendiri.

\section{Munaqosah Tahfizhul Quran}

Menurut (Humas Al Hikmah, 2016)

"Munaqosah berarti ujian, dan Munaqosah Tahfizhul Quran adalah ujian bagi para santri tahfizh atau penghafal Al-Quran untuk melihat seberapa dalam dan mutqin hafalan yang mereka miliki".

\section{Unified Modelling Language}

Menurut (Prihandoyo, 2018:127):

Unifield Modeling Language merupakan salah satu metode pemodelan visual yang digunakan dalam perancangan dan pembuatan sebuah software yang berorientasikan pada objek. UML merupakan sebuah standar penulisan 
atau semacam blue print dimana didalamnya termasuk sebuah bisnis proses, penulisan kelas-kelas dalam sebuah bahasa yang spesifik.

Terdapat beberapa diagram UML yang sering digunakan dalam pengembangan sebuah sistem, yaitu:

1. Use Case Diagram merupakan gambaran dari fungsionalitas yang diharapkan dari sebuah sistem, dan merepresentasikan sebuah interaksi antara aktor dan sistem. Didalam use case terdapat actor yang merupakan sebuah gambaran entitas dari manusia atau sebuah sistem yang melakukan pekerjaan di sistem.

2. Activity Diagram merupakan gambaran alir dari aktivitas-aktivitas didalam sistem yang berjalan.

3. Sequence Diagram menggambarkan interaksi antar objek didalam dan di sekitar sistem yang berupa message yang digambarkan terhadap waktu.

4. Class diagram merupakan gambaran struktur dan deskripsi dari class, package dan objek yang saling berhubungan seperti diantaranya pewarisan, asosiasi dan lainnya.

\section{METODE PENELITIAN}

Metode yang digunakan pada pengolahan data ini menggunakan metode AHP (Analytical Hierarcy Process) dalam membantu membuat keputusan, AHP (Analytic Hierarchy Process) adalah suatu teori umum tentang pengukuran yang digunakan untuk menemukan skala rasio, baik dari perbandingan berpasangan yang diskrit maupun kontinyu. AHP menguraikan masalah multi faktor atau multi kriteria yang kompleks menjadi suatu hirarki. Hirarki didefinisikan sebagai suatu representasi dari sebuah permasalahan yang kompleks dalam suatu struktur multi level dimana level pertama adalah tujuan, yang diikuti level faktor, kriteria, sub kriteria, dan seterusnya ke bawah hingga level terakhir dari alternatif. Dengan hirarki, suatu masalah yang kompleks dapat diuraikan ke dalam kelompokkelompoknyayang kemudian diatur menjadi suatu bentuk hirarki sehingga permasalahan akan tampak lebih terstruktur dan sistematis.

Tahapan-Tahapan dalam AHP (Analytic Hierarchy Process):
1. Mendefinisikan masalah dan menentukan solusi yang diinginkan.

2. Membuat struktur hierarki yang diawali dengan tujuan umum, dilanjutkan dengan kriteria-kriteria dan alternatif- alternatif pilihan.

\section{Struktur Hirarki AHP :}

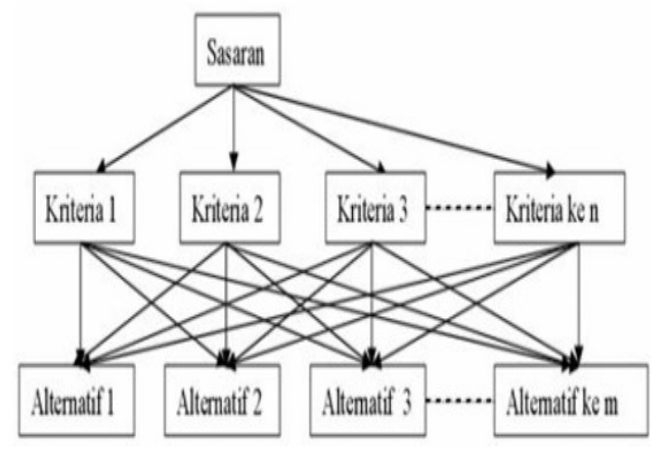

Gambar 1. Struktur Hirarki AHP

3. Membuat matrik perbandingan berpasangan yang menggambarkan kontribusi relatif atau pengaruh setiap elemen terhadap tujuan atau kriteria yang setingkat di atasnya. Perbandingan dilakukan berdasarkan pilihan atau judgement dari pembuat keputusan dengan menilai tingkat kepentingan suatu elemen dibandingkan elemen lainnya.

4. Menormalkan data yaitu dengan membagi nilai dari setiap elemenp di dalam matrik yang berpasangan dengan nilai total dari setiap kolom.

5. Menghitung nilai eigen vector dan menguji konsistensinya, jika tidak konsisten maka pengambilan data (preferensi) perlu diulangi. Nilai eigenvector yang dimaksud adalah nilai eigen vector maksimum yang diperoleh.

6. Mengulangi langkah 3, 4 dan 5 untuk seluruh tingkat hirarki.

7. Menghitung eigen vector dari setiap matriks perbandingan berpasangan. Nilaieigen vector merupakan bobot setiap elemen.

Menguji konsistensi hirarki. Jika tidak memenuhi dengan $\mathrm{CR}<0,100$ maka penilaian harus diulangi kembali.

\section{HASIL DAN PEMBAHASAN \\ Analisa Kebutuhan Pengguna}

Dalam website Munaqosah Madena Tahfizh Quran terdapat 3 pengguna yang saling berinteraksi dalam lingkungan sistem, yaitu: admin (pembina), munaqish (penguji) dan sekretaris.Ketiga pengguna tersebut memiliki karakteristik interaksi dengan sistem yang berbeda-beda dan memiliki kebutuhan informasi yang berbeda-beda, seperti berikut: 
a. Analisa Kebutuhan admin

1. Mengelola data santri madena

2. Mengelola data santri munaqosah

3. Melihat data hasilmunaqosah

4. Mengelola data nilai

5. Mengelola data preferensi

6. Mengelola data unit

7. Mengelola Sekretaris

8. Mengelola Munaqish

b. Analisis Kebutuhan Munaqish (Penguji)

1. Melihat data santri munaqosah

2. Menginput nilai munaqosah

3. Mengelola hasil penilaian

4. Melihat preferensi penilaian

5. Merubah akun saya

c. Analisis Kebutuhan Sekretaris

1. Mengelola data santri Madena

2. Menginput data santri munaqosah

3. Melihat hasilmunaqosah

4. Merubah akun saya

Kebutuhan Sistem

1. Pembina harus melakukan login terlebih dahulu untuk dapat mengakses aplikasi ini dengan memasukkan username dan password agar privasi masing-masing pengguna tetap terjaga keamanannya.

2. Sekretaris dan Munaqish dapat melakukan login setelah menerima username dan password dari Pembina.

3. Pembina harus melakukan logout setelah selesai menggunakan aplikasi.

4. Sistem melakukan pengelolaan penilaian hafalan terbaik dalam munaqosah tahfizhul quran.

\section{Diagram Unifed Modelling Language (UML) \\ Use Case Diagram Halaman Admin}

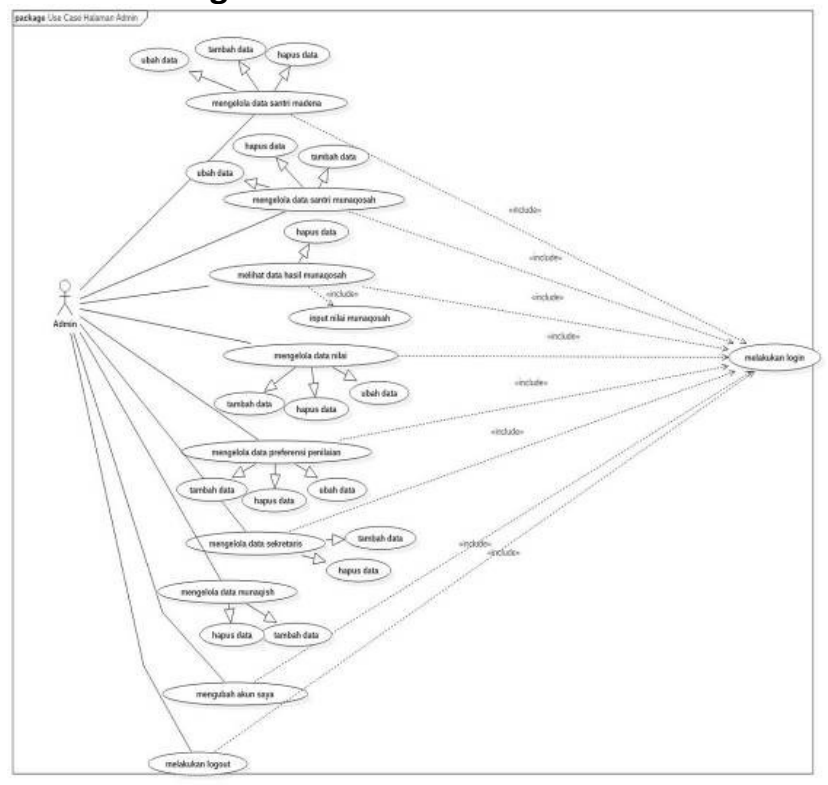

Gambar 2

Use Case Halaman Admin

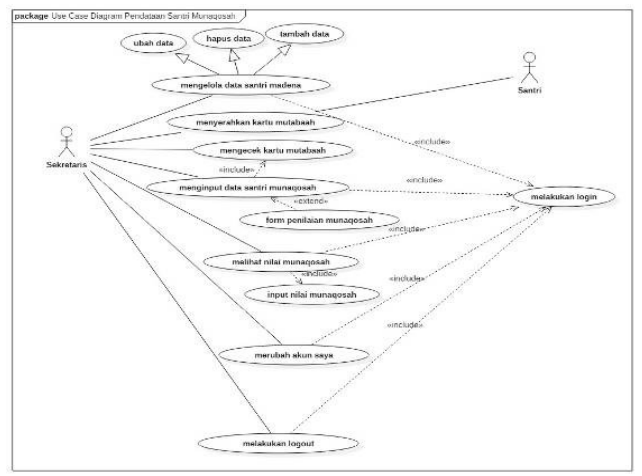

Gambar 3.

Use Case Pendataan Santri

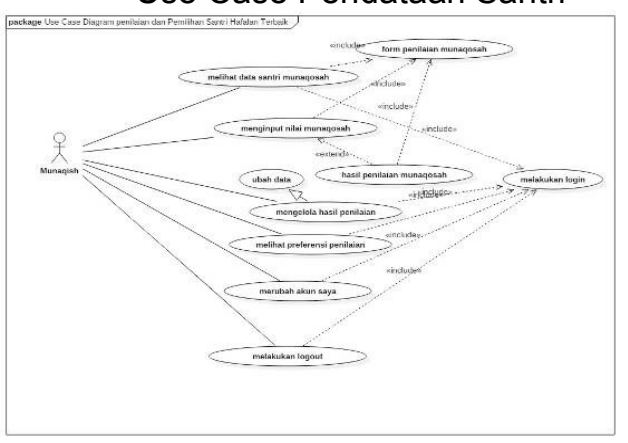

Gambar 4.

Use Case Diagram Penilaian dan Pemilihan Santri Hafalan Terbaik

\section{Rancangan Diagram Aktivitas}

gambaran alir dari aktivitasaktivitas didalam sistem yang berjalan

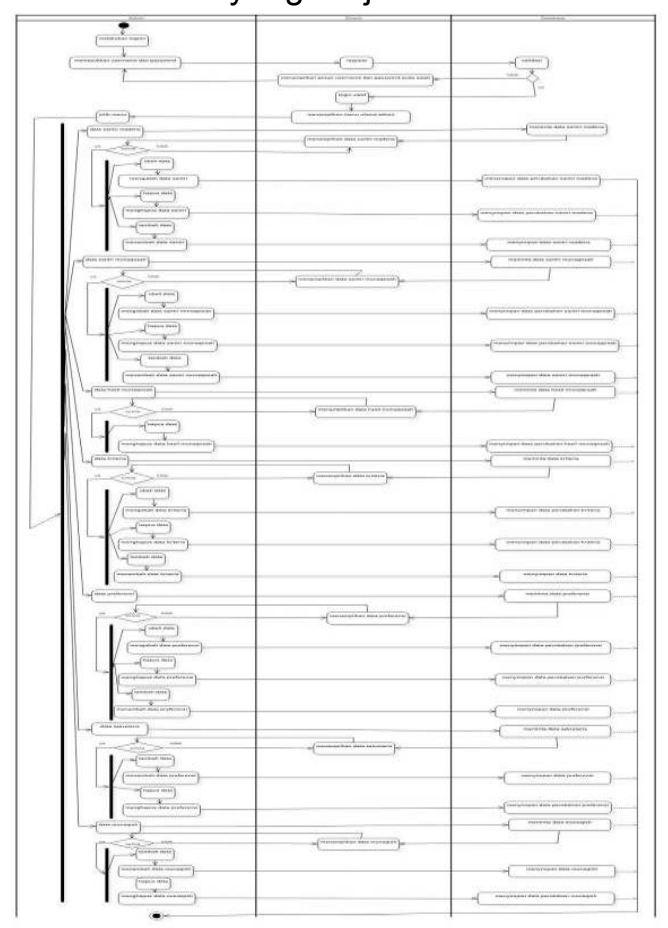

Gambar 5

Aktivitas Diagram Halaman Admin 


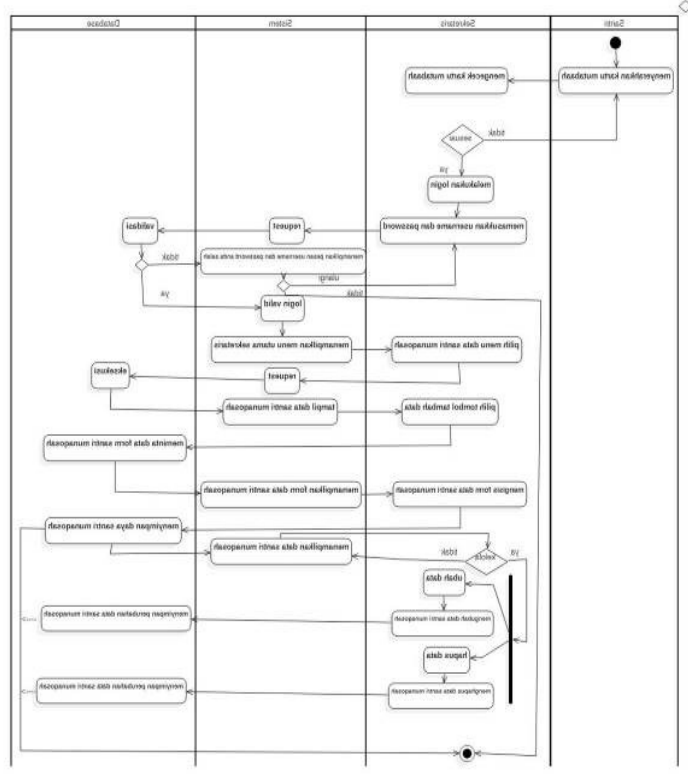

Gambar 6.

Aktivitas Diagram Pendataan Santri Munaqosah

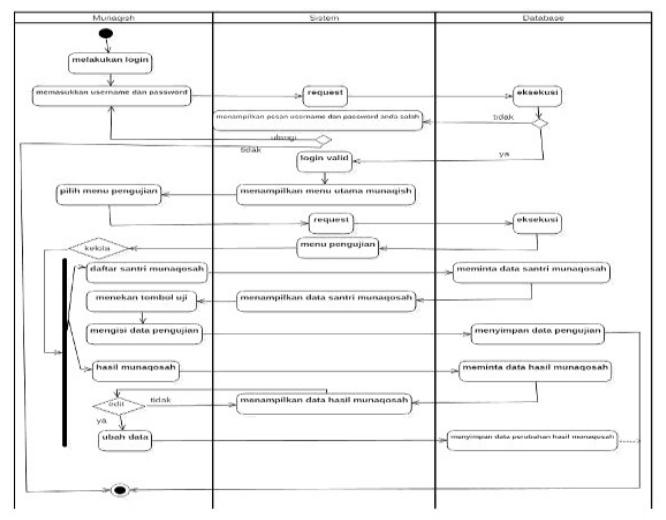

Gambar 7.

Aktivitas Diagram Penilaian dan Pemilihan Santri Hafalan Terbaik

\section{Rancangan Prototype}

Pengolahan Data Menggunakan Metode AHP

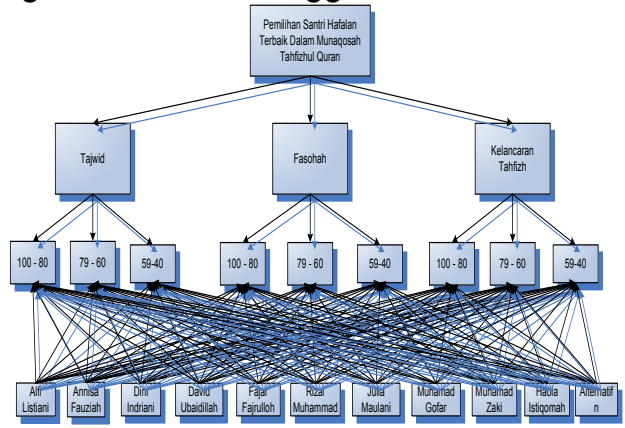

Gambar 8.

Struktur Hirarki Pemilihan Santri Hafalan Terbaik Dalam Munaqosah Tahfizhul Quran

\section{Langkah Penyelesaian:}

1. Tetapkan Permasalahan Menentukan santri dengan hafalan terbaik dalam munaqosahtahfizhul quran.
2. Menentukan Kriteria dan Sub Kriteria

a. Kriteria: Tajwid, Fasohah dan Kelancaran Tahfizh

b. Sub Kriteria Tajwid, Fasohah dan Kelancaran Tahfizh:
1) Mumtaz
$: 100-80$
2) Jayyid Jiddan
$: 79-60$
3) Jayyid
: $59-40$

3. Melakukan Penilaian Perbandingan Kriteria (Mengamati Kebijakan)

1) Tajwid 3 kali lebih penting dari Fasohah dan 4 kali lebih penting dari Kelancaran Tahfizh.

2) Fasohah 2 kali lebih penting dari Kelancaran Tahfizh.

4. Membentuk Matrik Pairwise Comparison (Matrik Perbandingan) Kriteria

\begin{tabular}{|l|c|c|c|}
\hline Kriteria & Tajwid & Fasohah & $\begin{array}{c}\text { Kelancaran } \\
\text { Tahfizh }\end{array}$ \\
\hline Tajwid & 1 & 3 & 4 \\
\hline Fasohah & $1 / 3$ & 1 & 2 \\
\hline $\begin{array}{l}\text { Kelancaran } \\
\text { Tahfizh }\end{array}$ & $1 / 4$ & $1 / 2$ & 1 \\
\hline
\end{tabular}

Keterangan:

1) Perbandingan terhadap dirinya sendiri akan menghasilkan nilai 1 , sehingganilai 1 akan tampil secara diagonal. Misalnya,(Tajwid terhadap Tajwid, Fasohah terhadap Fasohah, Kelancaran Tahfizh terhadap Kelancaran Tahfizh).

2) Perbandingan kolom kiri dengan kolom-kolom selanjutnya. Misalnya, nilai 3 didapatkan dari perbandingan Tajwid 3 kali lebih penting dari Fasohah.

3) Perbandingan kolom kiri dengan kolom-kolom selanjutnya. Misalnya,nilai 1/4didapatkan dari perbandingan Kelancaran Tahfizh dengan Tajwid, bahwa Tajwid 4 kali lebih penting dari Kelancaran Tahfizh sehingga nilai Kelancaran Tahfizh 1/4dari Tajwid.

5. Menentukan Rangking Kriteria Dalam Bentuk Vector Prioritas (Eigen Vector Normalisasi)

a. Ubah matrik Pairwise Comparison ke bentuk desimal dan jumlahkan tiap kolom tersebut

\begin{tabular}{|l|c|c|c|}
\hline \multicolumn{1}{|c|}{ Kriteria } & Tajwid & Fasohah & $\begin{array}{c}\text { Kelancaran } \\
\text { Tahfizh }\end{array}$ \\
\hline Tajwid & 1,00 & 3,00 & 4,00 \\
\hline Fasohah & 0,33 & 1,00 & 2,00 \\
\hline
\end{tabular}




\begin{tabular}{|l|c|c|c|}
\hline $\begin{array}{l}\text { Kelancaran } \\
\text { Tahfizh }\end{array}$ & 0,25 & 0,50 & 1,00 \\
\hline Jumlah & 1,58 & 4,5 & 7,00 \\
\hline
\end{tabular}

b. Bagi elemen-elemen tiap kolom dengan jumlah kolom yang bersangkutan

\begin{tabular}{|l|l|l|l|}
\hline Kriteria & Tajwid & Fasohah & $\begin{array}{c}\text { Kelancaran } \\
\text { Tahfizh }\end{array}$ \\
\hline Tajwid & 0,63 & 0,67 & 0,57 \\
\hline Fasohah & 0,21 & 0,22 & 0,29 \\
\hline $\begin{array}{l}\text { Kelancaran } \\
\text { Tahfizh }\end{array}$ & 0,16 & 0,11 & 0,14 \\
\hline Jumlah & 1,00 & 1,00 & 1,00 \\
\hline
\end{tabular}

Contoh: 0,63 didapat dari $1,00 / 1,58$ dan seterusnya

Jumlah tiap kolom kriteria harus berjumlah 1 , kalau penjumlahan tidak 1 maka ulangi normalisasi.

c. Hitung Eigen Vector Normalisasi dengan cara jumlahkan tiap baris kemudian dibagi dengan jumlah kriteria Jumlah kriteria (n) dalam kasus ini adalah 3

\begin{tabular}{|l|l|l|l|l|l|}
\hline Kriteria & $\begin{array}{l}\text { Tajw } \\
\text { id }\end{array}$ & $\begin{array}{l}\text { Fas } \\
\text { oha } \\
\mathrm{h}\end{array}$ & $\begin{array}{l}\text { Kelancar } \\
\text { an } \\
\text { Tahfizh }\end{array}$ & $\begin{array}{l}\text { Jumla } \\
\mathrm{h} \\
\text { Baris }\end{array}$ & $\begin{array}{l}\text { Eigen } \\
\text { Vector } \\
\text { Norma } \\
\text { lisasi }\end{array}$ \\
\hline Tajwid & 0,63 & 0,67 & 0,57 & 1,87 & 0,62 \\
\hline Fasohah & 0,21 & 0,22 & 0,29 & 0,72 & 0,24 \\
\hline $\begin{array}{l}\text { Kelanca } \\
\text { ran } \\
\text { Tahfizh }\end{array}$ & 0,16 & 0,11 & 0,14 & 0,41 & 0,14 \\
\hline & & & & Jumlah & 1,00 \\
\hline
\end{tabular}

Nilai 0,62 didapat dari $1,87 / 3$

Jumlah kolom EVN harus berjumlah 1

d. Menghitung rasio konsistensi untuk mengetahui apakah penilaian perbandingan kriteria bersifat konsisten 1) Menentukan Nilai $\lambda$ maks (Lamda Max)

Amaks diperoleh dengan menjumlahkan hasil perkalian jumlah kolom matrik Pairwise Comparison ke bentuk desimal dengan vector eigen normalisasi.

$\lambda$ maks $=\left(1,58^{\star} 0,62\right)+\left(4,5^{\star} 0,24\right)+$ $(7,00 * 0,14)$

Amaks $=3,04$

2) Menghitung Index Konsistensi (C1) $\mathrm{C} 1=($ Amaks-n) $/ \mathbf{n}-\mathbf{1}$

C1 $=(3,04-3) / 3-1$

$\mathrm{C} 1=0,02$

3) Menghitung Rasio Konsistensi $(\mathrm{CR})$

Nilai RI untuk $\mathrm{n}=3$ adalah 0,58 (Lihat Daftar Index Random Konsistensi/RI)

Daftar Index Random Konsistensi (RI)

\begin{tabular}{|l|l|l|l|l|l|l|l|l|l|l|l|l|l|l|l|}
\hline $\mathbf{N}$ & 1 & 2 & 3 & 4 & 5 & 6 & 7 & 8 & 9 & 10 & 11 & 12 & 13 & 14 & 15 \\
\hline $\mathbf{R I}$ & 0 & 0 & 0,58 & 0,9 & 1,12 & 1,24 & 1,32 & 1,41 & 1,45 & 1,49 & 1,51 & 1,48 & 1,56 & 1,57 & 1,59 \\
\hline
\end{tabular}

$\mathrm{CR}=\mathrm{Cl} / \mathrm{RI}$

$\mathrm{CR}=0,02 / 0,58$

CR $=0,03$

Karena $\mathrm{CR}<0,1$ berarti preferensi pembobotan adalah konsisten, jika CR > 0,1 maka ulangi langkah no 3 .

6. Melakukan penilaian Perbandingan Sub

Kriteria (Mengamati Kebijakan)

$\begin{array}{ll}\text { Mumtaz } & \text { : Sangat Baik } \\ \text { Jayyid Jiddan } & \text { : Cukup Baik } \\ \text { Jayyid } & \text { : Baik }\end{array}$

Jayyid : Baik

1) Mumtaz 3 kali lebih penting dari Jayyid Jiddan dan 4 kali lebih penting dari Jayyid.

2) Jayyid Jiddan 2 kali lebih penting dari Jayyid.
7. Membentuk Matrik Pairwise Comparison (Matrik Perbandingan) Kriteria

\begin{tabular}{|l|c|c|c|}
\hline Kriteria & Mumtaz & $\begin{array}{c}\text { Jayyid } \\
\text { Jiddan }\end{array}$ & Jayyid \\
\hline Mumtaz & 1 & 3 & 4 \\
\hline $\begin{array}{l}\text { Jayyid } \\
\text { Jiddan }\end{array}$ & $1 / 3$ & 1 & 2 \\
\hline Jayyid & $1 / 4$ & $1 / 2$ & 1 \\
\hline
\end{tabular}




\begin{tabular}{|l|c|c|c|}
\hline Kriteria & Mumtaz & $\begin{array}{c}\text { Jayyid } \\
\text { Jiddan }\end{array}$ & Jayyid \\
\hline Mumtaz & 1,00 & 3,00 & 4,00 \\
\hline $\begin{array}{l}\text { Jayyid } \\
\text { Jiddan }\end{array}$ & 0,33 & 1,00 & 2,00 \\
\hline Jayyid & 0,25 & 0,50 & 1,00 \\
\hline Jumlah & 1,58 & 4,5 & 7,00 \\
\hline
\end{tabular}

8. Menentukan Rangking Kriteria Dalam Bentuk vector Prioritas (Eigen Vector Normalisasi)

a. Ubah matrik Pairwise Comparison ke bentuk desimal dan jumlahkan tiap kolom tersebut

b. Bagi elemen-elemen tiap kolom dengan jumlah kolom yang bersangkutan

Contoh: 0,63 didapat dari 1,00/1,58 dan seterusnya

Jumlah tiap kolom kriteria harus berjumlah 1, kalau penjumlahan tidak 1 maka ulangi normalisasi.

c. Hitung Eigen Vector Normalisasi dengan cara jumlahkan tiap baris

6) Menghitung Rasio Konsistensi (CR)

kemudian dibagi dengan jumlah kriteria

Jumlah kriteria (n) dalam kasus ini adalah 3

\begin{tabular}{|l|c|c|c|c|c|}
\hline Kriteria & $\begin{array}{c}\text { Mum } \\
\text { taz }\end{array}$ & $\begin{array}{c}\text { Jayyid } \\
\text { Jiddan }\end{array}$ & $\begin{array}{c}\text { Jayyi } \\
\mathrm{d}\end{array}$ & $\begin{array}{c}\text { Jumlah } \\
\text { Baris }\end{array}$ & $\begin{array}{c}\text { Eige } \\
\mathrm{n} \\
\text { Vect } \\
\text { or }\end{array}$ \\
\hline Mumtaz & 0,63 & 0,67 & 0,57 & 1,87 & 0,62 \\
\hline $\begin{array}{l}\text { Jayyid } \\
\text { Jiddan }\end{array}$ & 0,21 & 0,22 & 0,29 & 0,72 & 0,24 \\
\hline Jayyid & 0,16 & 0,11 & 0,14 & 0,41 & 0,14 \\
\hline & & & \multicolumn{2}{|c|}{$\begin{array}{c}\text { Jumlah } \\
1,00\end{array}$} \\
\hline
\end{tabular}

Nilai 0,62 didapat dari $1,87 / 3$

Jumlah kolom EVN harus berjumlah 1

d. Menghitung rasio konsistensi untuk mengetahui apakah penilaian perbandingan kriteria bersifat konsisten

4) Menentukan Nilai $\lambda$ maks (Lamda Max) Amaks diperoleh dengan menjumlahkan hasil perkalian jumlah kolom matrik Pairwise Comparison ke bentuk desimal dengan vector eigen normalisasi.

$\lambda$ maks $=\left(1,58^{\star} 0,62\right)+\left(4,5^{\star} 0,24\right)+$ $\left(7,00^{*} 0,14\right)$

Amaks $=3,04$

5) Menghitung Index Konsistensi (C1)

C1 $=$ ( Amaks-n) $/ \mathbf{n}-1$

C1 $=(3,04-3) / 3-1$

$\mathrm{C} 1=0,02$

Nilai RI untuk $\mathrm{n}=3$ adalah 0,58 (Lihat Daftar Index Random Konsistensi/RI)

Daftar Index Random Konsistensi (RI)

\begin{tabular}{|l|l|l|l|l|l|l|l|l|l|l|l|l|l|l|l|}
\hline $\mathbf{N}$ & 1 & 2 & 3 & 4 & 5 & 6 & 7 & 8 & 9 & 10 & 11 & 12 & 13 & 14 & 15 \\
\hline $\mathbf{R I}$ & 0 & 0 & 0,58 & 0,9 & 1,12 & 1,24 & 1,32 & 1,41 & 1,45 & 1,49 & 1,51 & 1,48 & 1,56 & 1,57 & 1,59 \\
\hline
\end{tabular}

$\mathrm{CR}=\mathrm{Cl} / \mathrm{RI}$

$\mathrm{CR}=0,02 / 0,58$

$\mathrm{CR}=\mathbf{0 , 0 3}$

Karena CR $<0,1$ berarti preferensi pembobotan adalah konsisten, jika CR > 0,1 maka ulangi langkah no 3 .

9. Menentukan Rangking dari Alternatif Demgan Cara Menghitung Eigen Vektor Untuk Tiap Kriteria dan Sub Kriteria

Alternatif 1 : Alfi Listiani

Alternatif 2 : Annisa Fauziah

Alternatif 3 : Dini Indriani

Alternatif 4 : David Ubaidillah

Alternatif 5 : Fajar Fajrulloh

Alternatif 6 : Rizal Muhammad

Alternatif 7 : Julia Maulani

Alternatif 8 : Muhamad Gofar

Alternatif 9 : Muhamad Zaki
Alternatif 10 : Haola Istiqomah

Alternatif $\mathrm{n}$

Alternatif 1:

Alfi Listiani memiliki Nilai Tajwid 70, memiliki Nilai Fasohah 80 dan memiliki Nilai Kelancaran Tahfizh 85.

Alternatif 2:

Annisa Fauziah memiliki Nilai Tajwid 65, memiliki Nilai Fasohah 70 dan memiliki Nilai Kelancaran Tahfizh 72.

Alternatif 3:

Dini Indriani memiliki Nilai Tajwid 50, memiliki Nilai Fasohah 52 dan memiliki Nilai Kelancaran Tahfizh 60.

\section{Alternatif 4:}

David Ubaidillah memiliki Nilai Tajwid60, memiliki Nilai Fasohah65 dan memiliki Nilai Kelancaran Tahfizh70. 


\section{Alternatif 5:}

Fajar Fajrulloh memiliki Nilai Tajwid 70, memiliki Nilai Fasohah 70 dan memiliki Nilai Kelancaran Tahfizh 85.

Alternatif 6:

Rizal Muhamad memiliki Nilai Tajwid 80, memiliki Nilai Fasohah 60 dan memiliki Nilai Kelancaran Tahfizh82.

Alternatif 7:

Julia Maulani memiliki Nilai Tajwid 75, memiliki Nilai Fasohah 60 dan memiliki Nilai Kelancaran Tahfizh 75.

Alternatif 8:

Muhamad Gofar memiliki Nilai Tajwid 89, memiliki Nilai Fasohah 90 dan memiliki Nilai Kelancaran Tahfizh 90.

\section{Alternatif 9:}

Muhamad Zaki memiliki Nilai Tajwid 85, memiliki Nilai Fasohah 90 dan memiliki Nilai Kelancaran Tahfizh 90.

\section{Alternatif 10:}

Haola Istiqomah memiliki Nilai Tajwid 70, memiliki Nilai Fasohah 65 dan memiliki Nilai Kelancaran Tahfizh 60.

\section{Alternatif $\mathbf{n}$ \\ Rumus : Eigen Vektor Normalisasi Kriteria * Eigen Vektor Sub Kriteria}

Hasil $=\left(0,62^{*} 0,24\right)+\left(0,24^{*} 0,62\right)+$ $\left(0,14^{*} 0,62\right)=0,39$

$$
\left(0,14^{*} 0,24\right)=0,24
$$$$
=\left(0,62^{*} 0,24\right)+\left(0,24^{*} 0,24\right)+
$$

$$
\left(0,14^{*} 0,24\right)=0,15
$$

$$
=\left(0,62^{*} 0,14\right)+\left(0,24^{*} 0,14\right)+
$$

$\left(0,14^{*} 0,24\right)=0,24$

$$
=\left(0,62^{*} 0,24\right)+\left(0,24^{*} 0,24\right)+
$$

$\left(0,14^{\star} 0,62\right)=0,30$

$=\left(0,62^{*} 0,24\right)+\left(0,24^{*} 0,24\right)+$

$\left(0,14^{*} 0,62\right)=0,54$

$$
=\left(0,62^{*} 0,62\right)+\left(0,24^{*} 0,24\right)+
$$

$\left(0,14{ }^{*} 0,24\right)=0,24$

$$
=\left(0,62^{*} 0,24\right)+(0,24 * 0,24)+
$$

$\left(0,14^{*} 0,62\right)=0,63$

$$
=\left(0,62^{*} 0,62\right)+\left(0,24^{*} 0,62\right)+
$$

$\left(0,14^{*} 0,62\right)=0,63$

$$
=\left(0,62^{\star} 0,62\right)+\left(0,24^{\star} 0,62\right)+
$$

$\left(0,14^{\star} 0,24\right)=0,24$

$$
=(0,62 * 0,24)+(0,24 * 0,24)+
$$

$$
=\mathrm{n}
$$

\begin{tabular}{|l|l|l|l|l|l|}
\hline Alternatif & Tajwid & Fasohah & Kelancaran Tahfizh & Hasil & Keterangan \\
\hline Alfi Listiani & Jayyid Jiddan & Mumtaz & Mumtaz & 0,39 & Terbaik \\
\hline Annisa Fauziah & Jayyid Jiddan & Jayyid Jiddan & Jayyid Jiddan & 0,24 & Baik \\
\hline Dini Indriani & Jayyid & Jayyid & Jayyid Jiddan & 0,15 & Baik \\
\hline David Ubaidillah & Jayyid Jiddan & Jayyid Jiddan & Jayyid Jiddan & 0,24 & Baik \\
\hline Fajar Fajrulloh & Jayyid Jiddan & Jayyid Jiddan & Mumtaz & 0,30 & Baik \\
\hline$\ldots .$. & & & & & \\
\hline$\ldots .$. & & & & & \\
\hline$\ldots .$. & & & & & \\
\hline Rizal Muhammad & Mumtaz & Jayyid Jiddan & Jayyid Jiddan & & \\
\hline Julia Maulani & Jayyid Jiddan & Jayyid Jiddan & Jayyid Jiddan & & \\
\hline Muhamad Gofar & Mumtaz & Mumtaz & Mumtaz & & \\
\hline
\end{tabular}




\begin{tabular}{|l|l|l|l|l|l|}
\hline Muhamad Zaki & Mumtaz & Mumtaz & Mumtaz & 0,63 & Terbaik \\
\hline Haola Istiqomah & Jayyid Jiddan & Jayyid Jiddan & Jayyid Jiddan & 0,24 & Baik \\
\hline
\end{tabular}

Hasil Akhir : Jika hasil nilai >= 0,39 maka menjadi santri dengan hafalan terbaik.

Implementasi Sistem

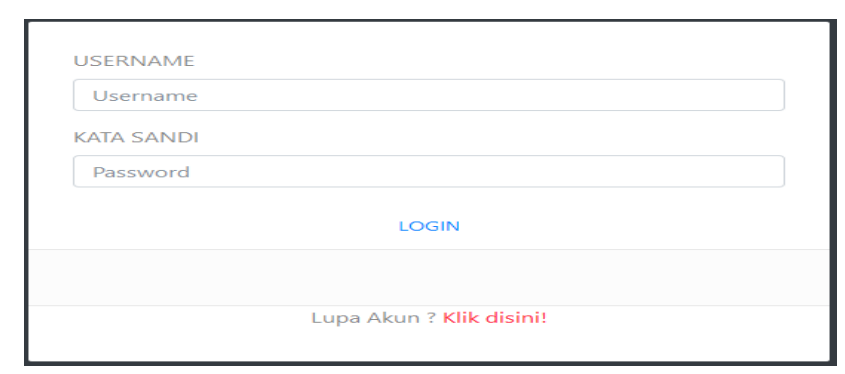

Gambar 9.

\section{Login Admin}

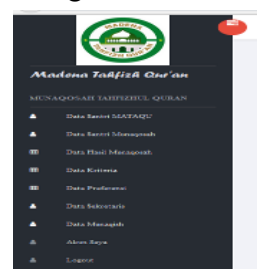

Gambar 10.

Menu Utama Admin

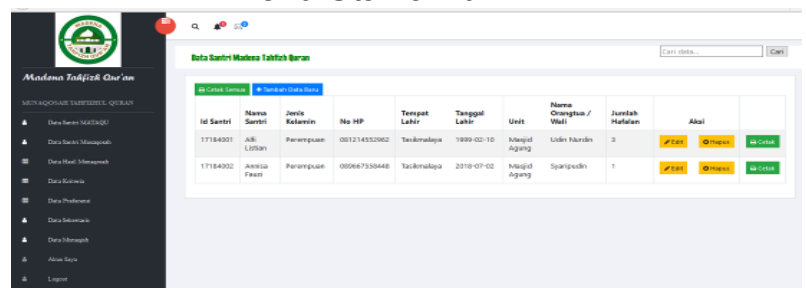

Gambar 11.

Data Santri Madena
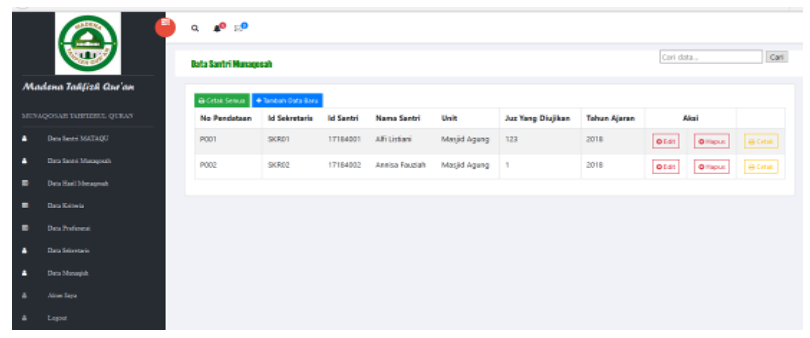

Gambar 12.

Data Santri Munaqosah

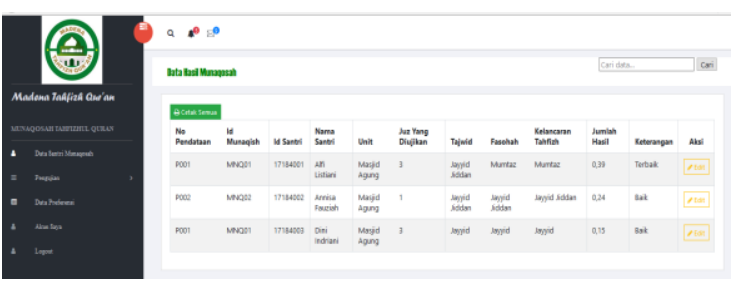

Gambar 13.

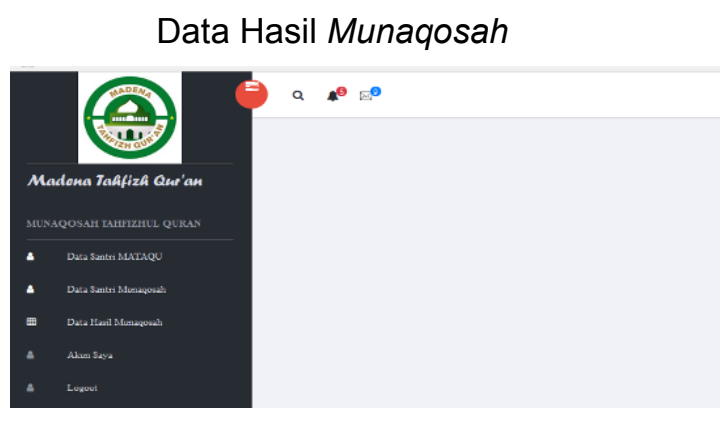

Gambar 14. Menu Utama Sekretaris

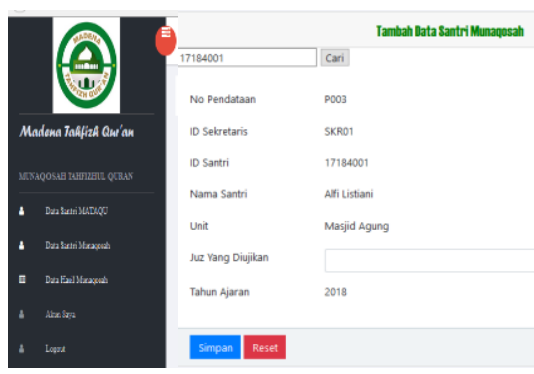

Gambar 15.

Tambah Data Santri Munaqosah

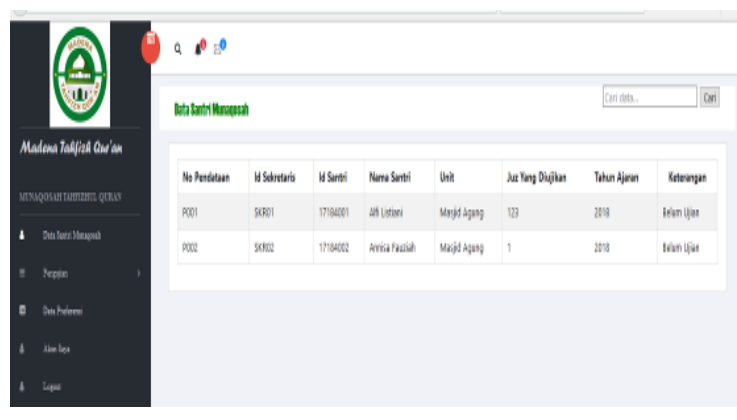

Gambar 16.

Tambah Data Santri Munaqosah(Munaqish)

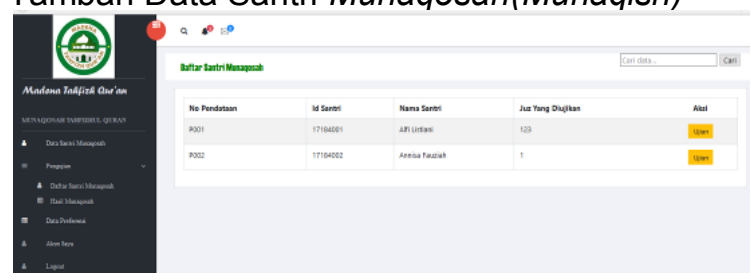

Gambar 17.

Daftar Santri Munaqosah 


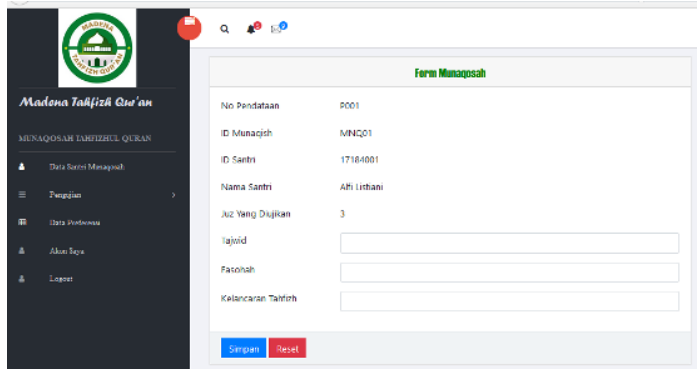

Gambar 18.

Penilaian Munaqosah
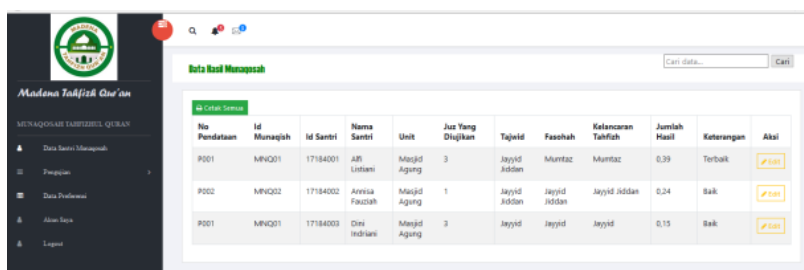

Gambar 19.

Hasil PeniaianMunaqosah

\section{Perancangan Perangkat Lunak}

1. Entity Relationship Diagram (ERD)

Menurut(Sari \& Yulianti, 2015:102):

ERD (Entity Relationship Diagram) merupakan pemodelan awal basis data yang paling banyak digunakan. ERD dikembangkan berdasarkan teori himpunan dalam bidang matematika. ERD juga digunakan dalam pemodelan basis data relasional.

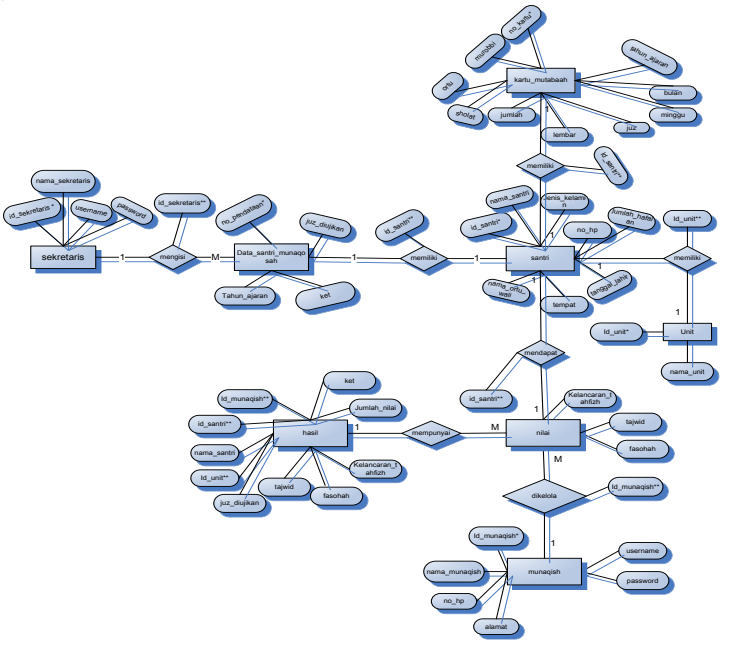

Gambar 20

Entity Relationship Diagram (ERD)

2. Logical Record Structure (LRS)

Menurut(Tasikmalaya, Informatika, \& Dci, 2018):

Logical Record Structure dibentuk dengan nomor dari tipe record. Beberapa tipe record digambarkan oleh kotak empat persegi panjang dan dengan nama yang unik. LRS terdiri dari link-link diantara tipe record. Link ini menunjukkan arah dari satu tipe record lainnya.

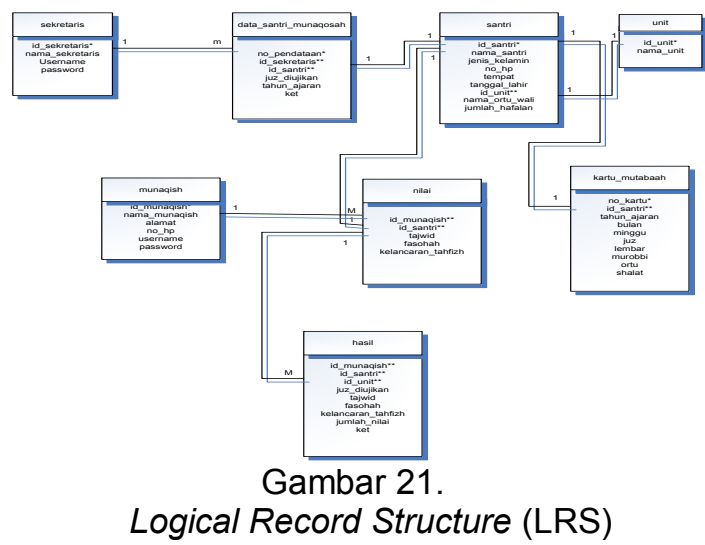

3. Class Diagram

Menurut (Prihandoyo, 2018:127):

gambaran struktur dan deskripsi dari class, package dan objek yang saling berhubungan seperti diantaranya pewarisan, asosiasi dan lainnya.

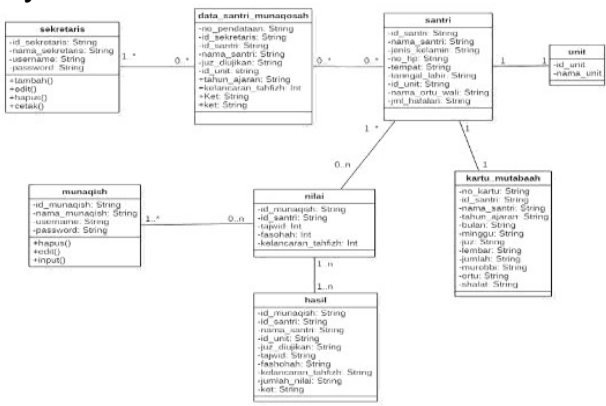

Gambar 22.

Class Diagram

\section{Sequence Diagram}

Menurut (Prihandoyo, 2018:127): menggambarkan interaksi antar objek didalam dan di sekitar sistem yang berupa message yang digambarkan terhadap waktu.

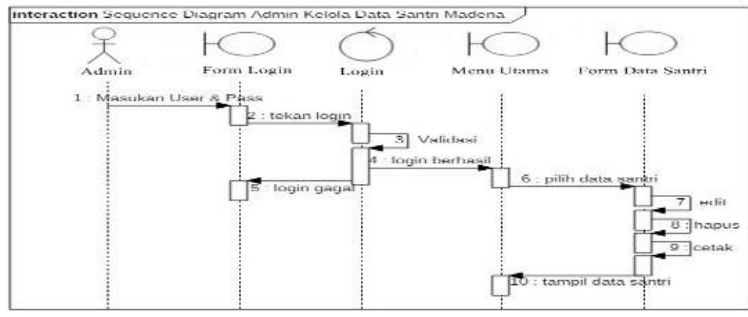

Gambar 23

Sequence Diagram Admin(Kelola Data Santri Madena) 


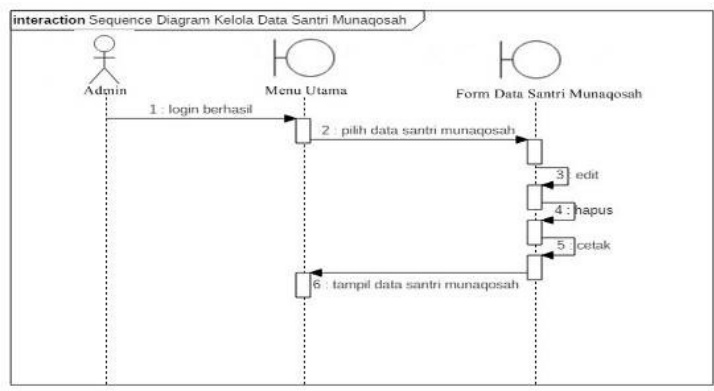

Gambar 24.

Sequence Diagram Admin(Kelola Data Santri Munaqosah)

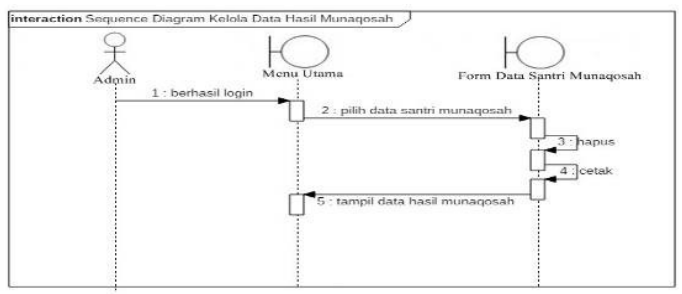

Gambar 25.

Sequence Diagram Admin(Kelola Data Hasil Munaqosah)

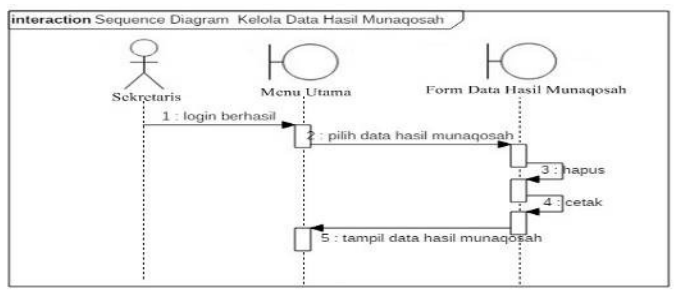

Gambar 26.

Sequence Diagram Sekretaris (Kelola Data Santri Munaqosah)

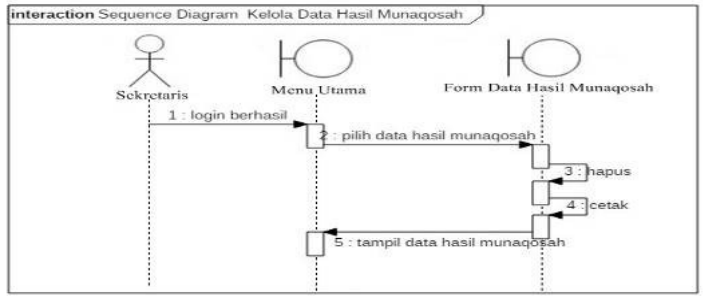

Gambar 27.

Sequence Diagram Sekretaris (Kelola Data HasilMunaqosah)

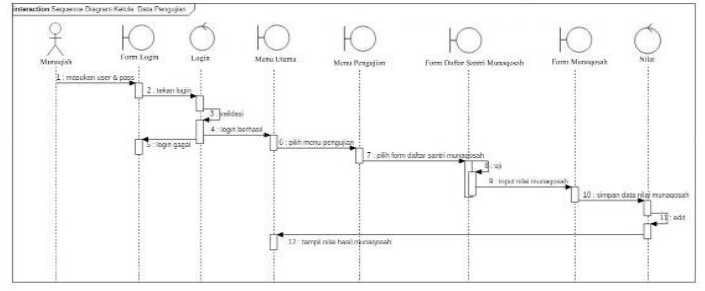

Gambar 28.

Sequence Diagram Munaqish (Kelola Data Pengujian)

\section{E. KESIMPULAN}

1. Dengan diterapkannya Sistem Pendukung Keputusan berbasis komputer, diharapkan dapat memberikan kemudahan-kemudahan bagi pelaksanaan Munaqosah Tahfizhul Quran pada Rumah Tahfizh Madena dalam mengelola nilai dan data santri, sehingga mampu menentukan santri dengan hafalan terbaik.

2. Dapat membantu pengurus rumah tahfizh dalam melakukan rekapitulasi data, pengelolaan penilaian munaqosah dan pembuatan laporan.

\section{DAFTAR PUSTAKA}

[1] Iswandy, E., Sekolah, D., Manajemen, T., Komputer, I., \& Balantai, B. (2015). Jurnal Teknoif ISSN : 2338-2724 Sistem Penunjang Keputusan Untuk Menentukan Penerimaan Mahasiswa Dan Pelajar Kurang Mampu Vol . 3 No . 2 Oktober 2015 Jurnal Teknoif ISSN : 2338-2724, $3(2)$.

[2] Jannah, R. (2015). Aplikasi Penerimaan Karyawan dengan Metode Multi Attribute Utility Theory. SATIN-Sains Dan Teknologi Informasi, 1(2), 79-89.

[3] Sintawati, I. D., \& Sari, A. M. (2017). Perlengkapan Tidur Berbasis Web. Paradigma, 19(2), 127-130.

[4] Komputer, Jurusan Teknik, Politeknik Harapan, and Bersama Tegal. 2018. "Unified Modeling Language ( UML ) Model Untuk Pengembangan Sistem Informasi Akademik Berbasis Web." 03(01): 126-29. 